\title{
Frequency and pattern of expression of the stem cell marker CD133 have strong prognostic effect on the surgical outcome of colorectal cancer patients
}

\author{
SHUSAKU TAKAHASHI ${ }^{1}$, TOSHIYA KAMIYAMA ${ }^{3}$, UTANO TOMARU ${ }^{4}$, AKIHIRO ISHIZU $^{6}$, \\ TOSHIYUKI SHIDA ${ }^{2}$, MINEJI OSAKA $^{2}$, YUTAKA SATO ${ }^{2}$, YUTAKA SAJI ${ }^{1}$ \\ MICHITAKA OZAKI $^{5}$ and SATORU TODO ${ }^{3}$
}

\begin{abstract}
Departments of ${ }^{1}$ Surgery, and ${ }^{2}$ Pathology, Tomakomai City Hospital, 1-5-20 Shimizu-machi, Tomakomai 053-8567, Hokkaido; Departments of ${ }^{3}$ General Surgery, ${ }^{4}$ Pathology, ${ }^{5}$ Molecular Surgery, and ${ }^{6}$ Faculty of Health Science, Hokkaido University Graduate School of Medicine, North 15, West 7, Kita-ku, Sapporo, 060-8638, Hokkaido, Japan
\end{abstract}

Received June 11, 2010; Accepted July 29, 2010

DOI: 10.3892/or_00000973

\begin{abstract}
CD133 has been reported to be a cancer stem cell marker in colorectal cancer (CRC). The aim of this study was to examine the frequency and pattern of CD133 expression by immunohistochemical methods and evaluate their correlation with clinicopathological features, including patient survival (PS) and recurrence. Tissue specimens of 151 CRC patients who underwent surgical treatment for well-differentiated/moderately differentiated adenocarcinoma and stage I-IV tumors (TNM classification) were immunostained for analyzing CD133 expression. The frequency of CD133 expression was $91.4 \%$ (138/151), and the pattern of expression was divided into membranous and cytoplasmic expression. Of the 151 patients, $136(90.1 \%)$ showed membranous expression, whereas $44(29.1 \%)$ showed cytoplasmic expression. Both expression patterns were seen in $42(27.8 \%)$ patients. The frequency of CD133 overexpression (>50\% of stained cells) was $27.2 \%$ (41/151); univariate analysis showed CD133 overexpression to be significantly associated with PS, but not recurrence, and multivariate analysis indicated it to be an independent prognostic factor. Multivariate analysis showed membranous overexpression ( $>50 \%$ of stained tumor cells on the membrane), which significantly correlated with histology and chemoresistance of recurrent and stage IV tumors, to be an independent prognostic factor for PS and recurrence. However, multivariate analysis did not indicate cytoplasmic expression, which significantly correlated with histology, lymph node metastasis, TNM stage and lymphatic
\end{abstract}

Correspondence to: Dr Shusaku Takahashi, Department of Surgery, Tomakomai City Hospital, 1-5-20 Shimizu-machi, Tomakomai 053-8567, Hokkaido, Japan

E-mail: shusaku@poppy.ocn.ne.jp

Key words: CD133, cancer stem cell, colorectal cancer, prognosis invasion, as an independent prognostic factor for PS and recurrence. Our results demonstrated that evaluation of the frequency and pattern of CD133 expression is useful for predicting prognosis, recurrence, and chemosensitivity in CRC patients.

\section{Introduction}

Colorectal cancer (CRC) is one of the most common types of cancer in the world (1). Although surgery is a common treatment option for CRC, a previous study reported the recurrence rate after curative surgery to be $17.3 \%$ and an overall 5-year survival rate of surgically treated CRC patients to be $69.9 \%$, with that of stage IV patients to be $13.2 \%$ (2). Despite the recent advances in systemic chemotherapy drugs such as camptothecin (CPT-11), oxaliplatin, cetuximab, panitumumab, and bevacizumab, recurrence after surgery is a major problem and often the cause of death (3-6).

For many years, it has been thought that all cancer cells have the ability of tumorigenic growth. However, recent evidence has shown the existence of a small population of cancer cells that are tumorigenic and have the ability of self-renewal, and these cells are termed 'cancer stem cells' (7). The first evidence came from a study of human acute myeloid leukemia in 1997 (8). Currently, different approaches [expression of surface markers $(9,10)$, sphere formation (10-12), and isolation of side-population cells on the basis of efflux of Hoechst 33342 dye $(13,14)$ ] are used for the isolation of cancer stem cells. From the concept of cancer stem cells, it is considered that all cancer cells differentiate from cancer stem cells, and the latter are the cause of metastasis, resistance against treatment (chemotherapy and radiotherapy), and recurrence $(7,15)$.

CD133 is a member of the family of $120-\mathrm{kDa}$ transmembrane glycoproteins and considered to be a hematopoietic stem cell marker mainly expressed in the bone marrow, fetal liver, umbilical-cord blood, and peripheral blood before or after mobilization (16). However, this protein has been identified as a potential cancer stem cell marker in the brain 
(17), colon $(9,10)$, prostate (18), and pancreas (19). Although the biological function of CD133 remains largely unknown (16), the percentage of CD133-positive cancer stem cells clinically correlates with tumor aggressiveness (17) and poor prognosis $(20,21)$.

In CRC, CD133 is considered to be the most important surface marker of cancer stem cells because subpopulations of CD133-positive colon cancer cells have shown increased tumorigenic potential in transplantation studies in vitro and in vivo $(10,11)$. Thus far, some studies have reported a correlation between the frequency of CD133 expression and clinicopathological features, including patient survival (PS), by using clinical samples of CRC $(22,23)$. However, there are only a few reports on the clinical significance of the pattern of CD133 expression (membranous or cytoplasmic).

The aim of this study was to examine CD133 expression in surgical specimens of CRC by immunohistochemical methods, to evaluate the correlation of the frequency and pattern of CD133 expression with clinicopathological features, and to determine the prognostic significance of the frequency and pattern of CD133 expression.

\section{Materials and methods}

Patients and follow-up. Between January 2001 and December 2007, 175 consecutive patients with primary CRC were surgically treated at Tomakomai City Hospital. Of these, 151 patients who underwent surgical treatment for well-differentiated/moderately differentiated adenocarcinoma and stage I-IV tumors [tumor-node-metastasis (TNM) classification] were enrolled in this study. Stage 0 (Tis), multiple CRC, and multiple primary cancer patients were excluded from the study because of difficulties encountered in the evaluation of PS and recurrence. None of the patients received any preoperative therapy, but most of the stage IIIV patients received adjuvant chemotherapy. All the patients were followed up, at least, every 3-6 months by computed tomography and measurement of serum levels of tumor markers [carcinoembryonic antigen (CEA) and carbohydrate antigen (CA19-9)] and every 1-2 years by colonoscopy for PS and recurrence-free survival (RFS). Recurrence was defined as initial tumor recurrence. Metastasis or local recurrence was considered on evidence of tumor relapse. Only deaths due to CRC were included in the survival analysis.

Pathological and immunohistochemical analyses. Tissue specimens obtained from the patients were fixed in $10 \%$ formalin, embedded in paraffin, and cut into $4-\mu \mathrm{m}$-thick sections. Subsequently, they were stained with hematoxylin and eosin (H\&E). Tumor grade and stage were defined according to the TNM classification. The most representative sections were carefully selected and used for immunohistochemical analysis. Immunohistochemical staining for CD133 expression was performed on a Ventana Bench Mark XT autostainer with ultraView universal diaminobenzidine (DAB) detection kit (Ventana Medical Systems, Inc.). In brief, the sections were deparaffinized, washed, and immersed in citrate buffer (0.01 M, pH 6.0) for antigen retrieval. Endogenous peroxidase activity was blocked with $3 \%$ hydrogen peroxide, and the slides were rinsed and treated with a blocking solution to prevent non-specific staining. The sections were then incubated with a CD133-specific rabbit polyclonal antibody (rabbit anti-human polyclonal CD133; dilution, 1:200; ab19898; Abcam, Cambridge, UK) for $45 \mathrm{~min}$. After brief buffer washes, the sections were treated with biotinylated anti-rabbit immunoglobulin $\mathrm{G}(\mathrm{IgG})$ for $30 \mathrm{~min}$, washed, and then incubated with avidin-biotin-peroxidase complex for $30 \mathrm{~min}$. Thereafter, the sections were rinsed, developed with DAB and hydrogen peroxide, rinsed with tap water, and then counterstained with hematoxylin. Specificity of the antibodies was confirmed in parallel negative-control sections by omitting the primary antibody for each immunohistochemical procedure. Histopathological examination was independently performed by 2 pathologists (U.T. and A.I.).

Statistical analysis. Clinicopathological data and CD133 expression were statistically analyzed using the $\chi^{2}$ and Student's t-tests. PS and RFS were calculated using the Kaplan-Meier method, and the resulting curves were compared by the logrank test. Prognostic factors were analyzed univariately and multivariately (Cox's proportional hazards regression model). A P-value of $<0.05$ was considered statistically significant. Statistical analysis was performed and graphical presentation was prepared using the Ekuseru-Toukei 2008 software for Windows (Social Survey Research Information Co., Ltd., Tokyo, Japan).

\section{Results}

Clinicopathological findings. Clinicopathological data of the 151 patients are provided in Table I. The mean age of the patients was 67.1 years (range, 33-89 years). The patients comprised 89 men and 62 women. The pathological diagnosis was well-differentiated adenocarcinoma in 59 patients and moderately differentiated adenocarcinoma in 92 patients. According to the TNM classification, 28 patients were in stage I, 45 in stage II, 41 in stage III, and 37 in stage IV (liver metastasis in 26 patients). Lymphatic invasion was observed in 113 patients, and vascular invasion in 81 patients.

Follow-up. The median follow-up period was 41 months (range, 3-98 months). Of the 151 patients, 45 (29.8\%) died. The causes of death were: CRC $(n=38)$, other cancers $(n=4)$, and other diseases $(n=3)$. Of the 114 stage I-III patients who underwent curative surgery, 27 (23.7\%) showed recurrence during the follow-up period.

Immunohistochemical findings of CD133 expression. CD133 expression in tumor cells was observed on the cell membrane as apical membranous staining and in the cytoplasm as a strong dotty or uniform pattern (Fig. 1). Of the 151 patients, $138(91.4 \%)$ were positive for CD133, the expression of which was observed on the membrane and/or in the cytoplasm, whereas $13(8.6 \%)$ were negative for CD133. With regard to CD133 expression, the patients were divided into 2 categories: i) those with none or $\leq 50 \%$ of stained tumor cells in the entire tumor area were defined as 'CD133 overexpression negative'; and ii) those with $>50 \%$ of stained tumor cells in the entire tumor area were defined as 'CD133 overexpression positive' (Fig. 2). Of the 151 patients, 41 (27.2\%) were 
Table I. Clinicopathological findings.

Characteristics

\begin{tabular}{ll}
\hline No. of patients & $\mathrm{n}(\%) 151(100)$ \\
\hline
\end{tabular}

Age

Year $($ mean $\pm \mathrm{SD})$

$67.1 \pm 10.4$

Sex

Male

89 (58.9)

Female

$62(41.1)$

Tumor size

mm (mean $\pm \mathrm{SD})$

$48.5 \pm 24.9$

Tumor location

Colon

99 (65.6)

Right

$52(34.4)$

$47(31.1)$

$52(34.4)$

Rectum

Histology

Well

$59(39.1)$

Mod

$92(60.9)$

TNM parameter (T)

$\mathrm{T} 1$

17 (11.3)

21 (13.9)

$76(50.3)$

$37(24.5)$

T4

79 (52.3)

$44(29.1)$

$28(18.6)$

N2

$125(82.8)$

$26(17.2)$

$114(75.5)$

37 (24.5)

M1

IV

Present

Absent

$81(53.6)$

Present

$\mathrm{SD}$, standard deviation; well, well-differentiated adenocarcinoma; mod, moderately differentiated adenocarcinoma; TNM, tumornode-metastasis.
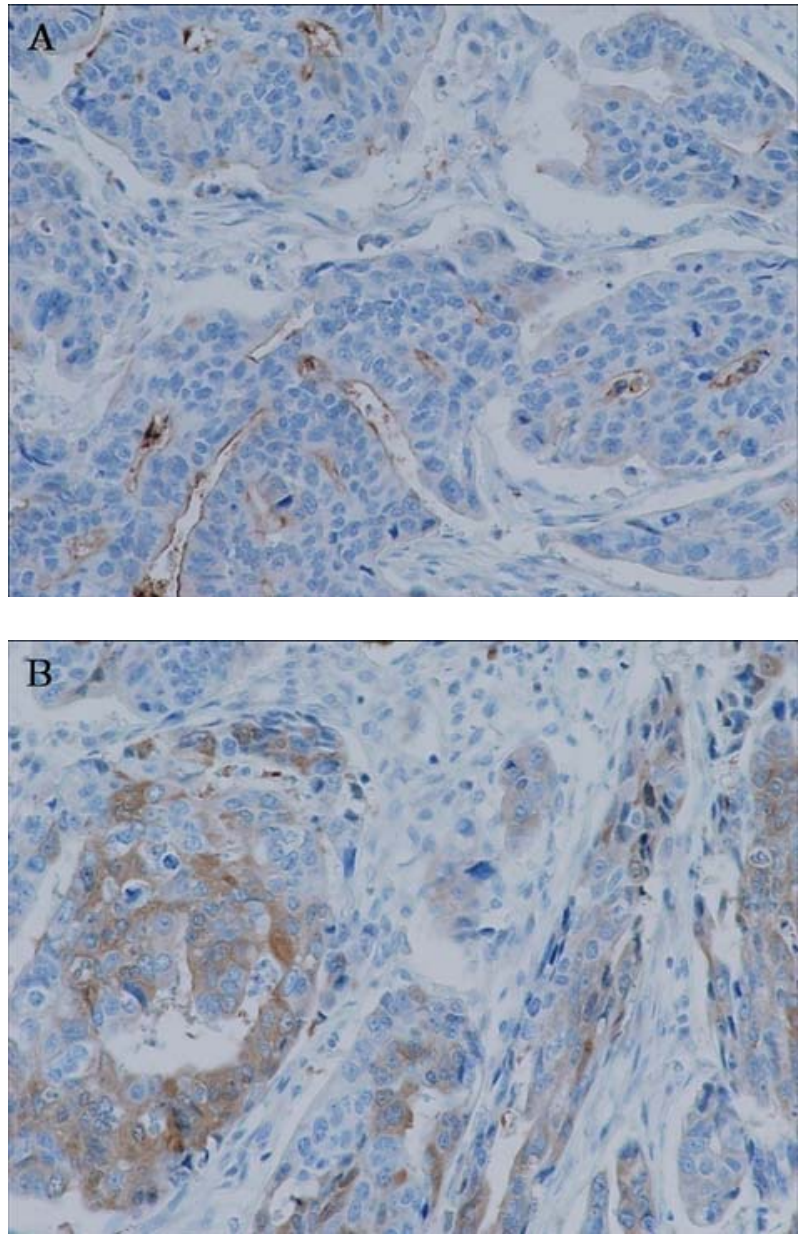

Figure 1. CD133 expression in tumor cells was observed on the cell membrane as apical membranous staining (A) and in the cytoplasm as a strong dotty or uniform pattern (B).

CD133 overexpression positive and 110 (72.8\%) were CD133 overexpression negative (Table III). When CD133 expression pattern was analyzed separately on the basis of staining results, i.e., membranous and cytoplasmic staining (Fig. 1), membranous expression was observed in $136(90.1 \%)$ patients and cytoplasmic expression in $44(29.1 \%)$ patients. In 42 (27.8\%) patients, CD133 expression was observed both on the membrane and in the cytoplasm. Only membranous expression without cytoplasmic expression was observed in $94(62.3 \%)$ patients, and only cytoplasmic expression without membranous expression was observed in $2(1.3 \%)$ patients (Table II). The CD133-expressing tumor cells were divided into 2 categories on the basis of distribution of expression: i) those showing membranous and cytoplasmic CD133 expression in separate areas (Fig. 3A-C) and ii) those showing membranous and cytoplasmic CD133 expression in the same areas (Fig. 3D-F).

Correlation between CD133 overexpression and clinicopathological features. As shown in Table III, there was no significant correlation of CD133 overexpression with age, sex, tumor size, tumor location, histology, TNM classification, liver metastasis, lymphatic invasion, or vascular invasion. 

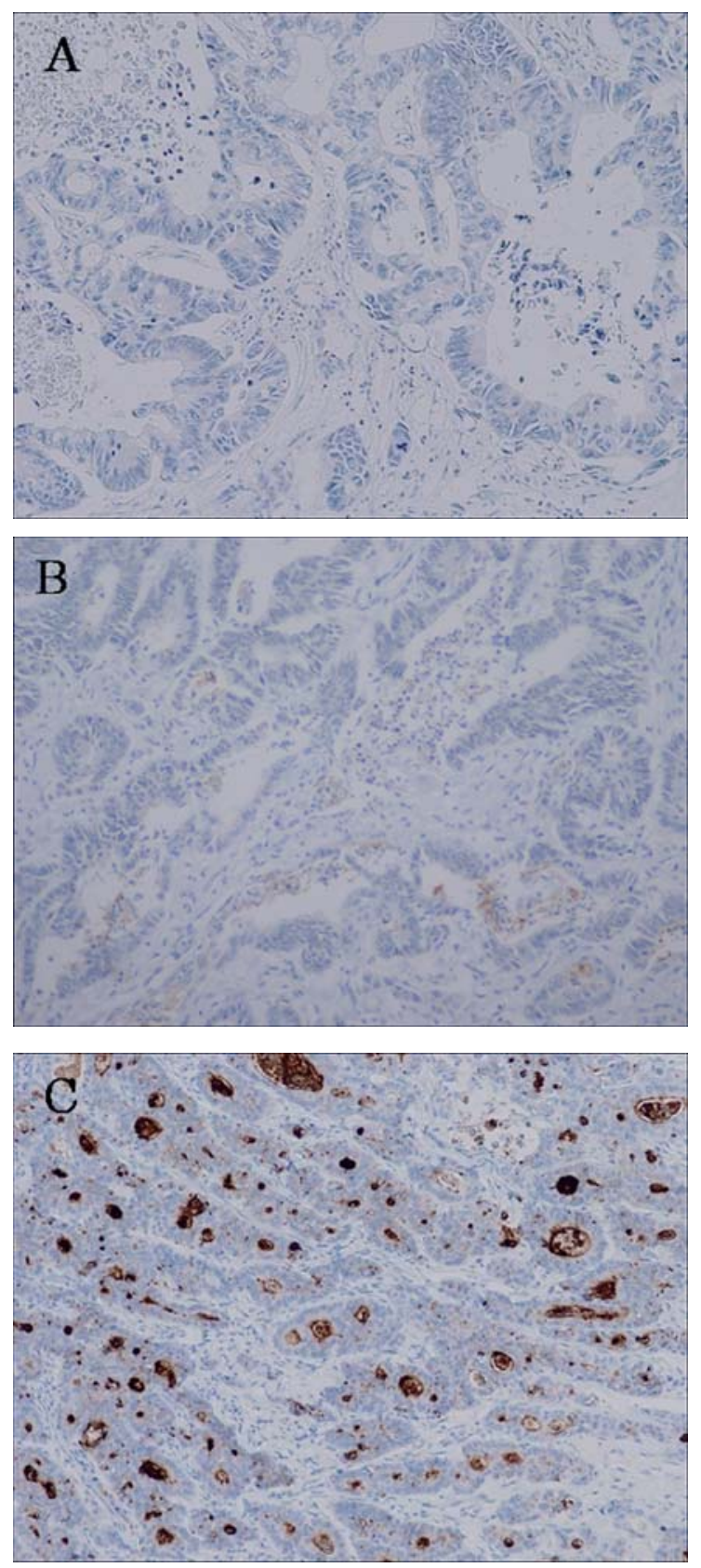

Figure 2. Classification of CRC cells on the basis of CD133 expression. Unstained cells (A), $\leq 50 \%$ of stained cells (B) (CD133 overexpressionnegative patients) and $>50 \%$ positivity of stained cells (C) (CD133 overexpression-positive patients). Original magnification, x200 .

Table II. Correlation between membranous and cytoplasmic expression of CD133 in CRC patients.

\begin{tabular}{lrrr}
\hline & \multicolumn{2}{c}{ Cytoplasmic expression } \\
\cline { 2 - 3 } & $(-)$ & $(+)$ & Total \\
\hline Membranous expression & & & \\
$(-)$ & 13 & 2 & 15 \\
$(+)$ & 94 & 42 & 136 \\
Total & 107 & 44 & 151 \\
\hline $\mathrm{p}=0.15$. & & & \\
\hline
\end{tabular}

Table III. Correlation between CD133 overexpression and clinicopathological features.

\begin{tabular}{lccc}
\hline & \multicolumn{2}{c}{ CD133 overexpression } & \\
\cline { 2 - 3 } No. of patients & Negative & Positive & \\
& 110 & 41 & P-value \\
\hline
\end{tabular}

Age

Year $($ mean \pm SD) $\quad 66.5 \pm 10.1 \quad 68.8 \pm 11.1 \quad 0.22$

Sex

$\begin{array}{llll}\text { Male } & 64 & 25 & 0.76 \\ \text { Female } & 46 & 16 & \end{array}$

Tumor size

mm (mean \pm SD) $\quad 47.2 \pm 22.3 \quad 51.9 \pm 30.8 \quad 0.3$

Tumor location

$\begin{array}{llrr}\text { Right } & 30 & 22 & 0.4 \\ \text { Left } & 40 & 7 & \\ \text { Rectum } & 40 & 12 & \end{array}$

Histology

Well

$41 \quad 18$

0.46

Mod

$69 \quad 23$

TNM parameter $(\mathrm{T})$

T1

$\mathrm{T} 2$

T3

$\mathrm{T} 4$

14

3

$\mathrm{T} 1+\mathrm{T} 2 \mathrm{vs}$

$\mathrm{T} 3+\mathrm{T} 4$

129

0.48

$62 \quad 14$

$22 \quad 15$

TNM parameter $(\mathrm{N})$

$\begin{array}{lrrc}\text { N0 } & 58 & 21 & \mathrm{~N}(-) \text { vs. N(+) } \\ \text { N1 } & 35 & 9 & 0.86 \\ \text { N2 } & 17 & 11 & \end{array}$

Liver metastasis

$\begin{array}{lrrr}\text { Absent } & 90 & 35 & 0.61 \\ \text { Present } & 20 & 6 & \end{array}$

TNM parameter $(\mathrm{M})$

$\begin{array}{llll}\text { M0 } & 84 & 30 & 0.68 \\ \text { M1 } & 26 & 11 & \end{array}$

TNM stage

\begin{tabular}{lrrc} 
I & 19 & 9 & I + II vs. III + IV \\
II & 34 & 11 & 0.94 \\
III & 31 & 10 & \\
IV & 26 & 11 & \\
Lymphatic invasion & & & \\
Absent & 27 & 11 & 0.77 \\
Present & 83 & 30 & \\
Vascular invasion & & & \\
Absent & 52 & 18 & 0.71 \\
Present & 58 & 23 & \\
\hline
\end{tabular}

SD, standard deviation; well, well-differentiated adenocarcinoma; mod, moderately differentiated adenocarcinoma; TNM, tumornode-metastasis. 

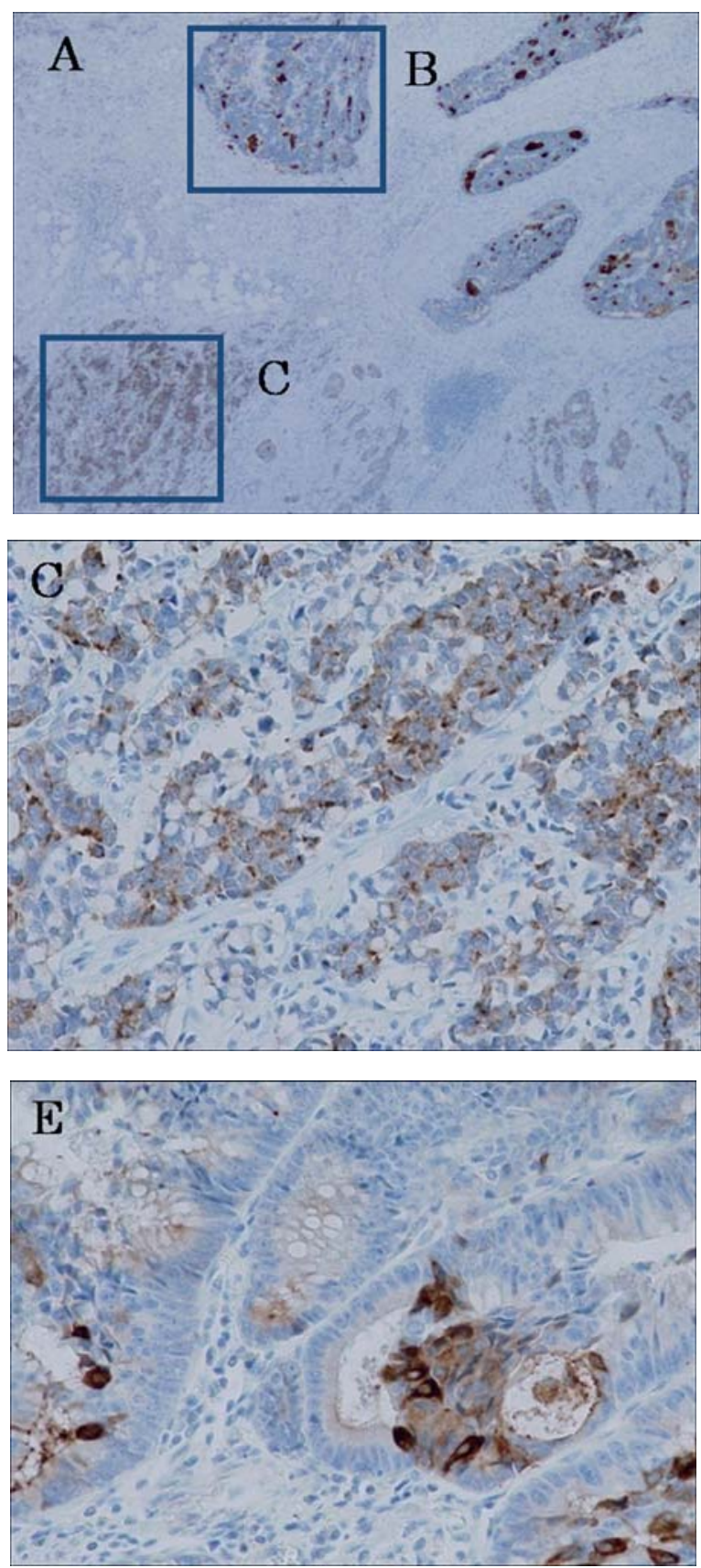
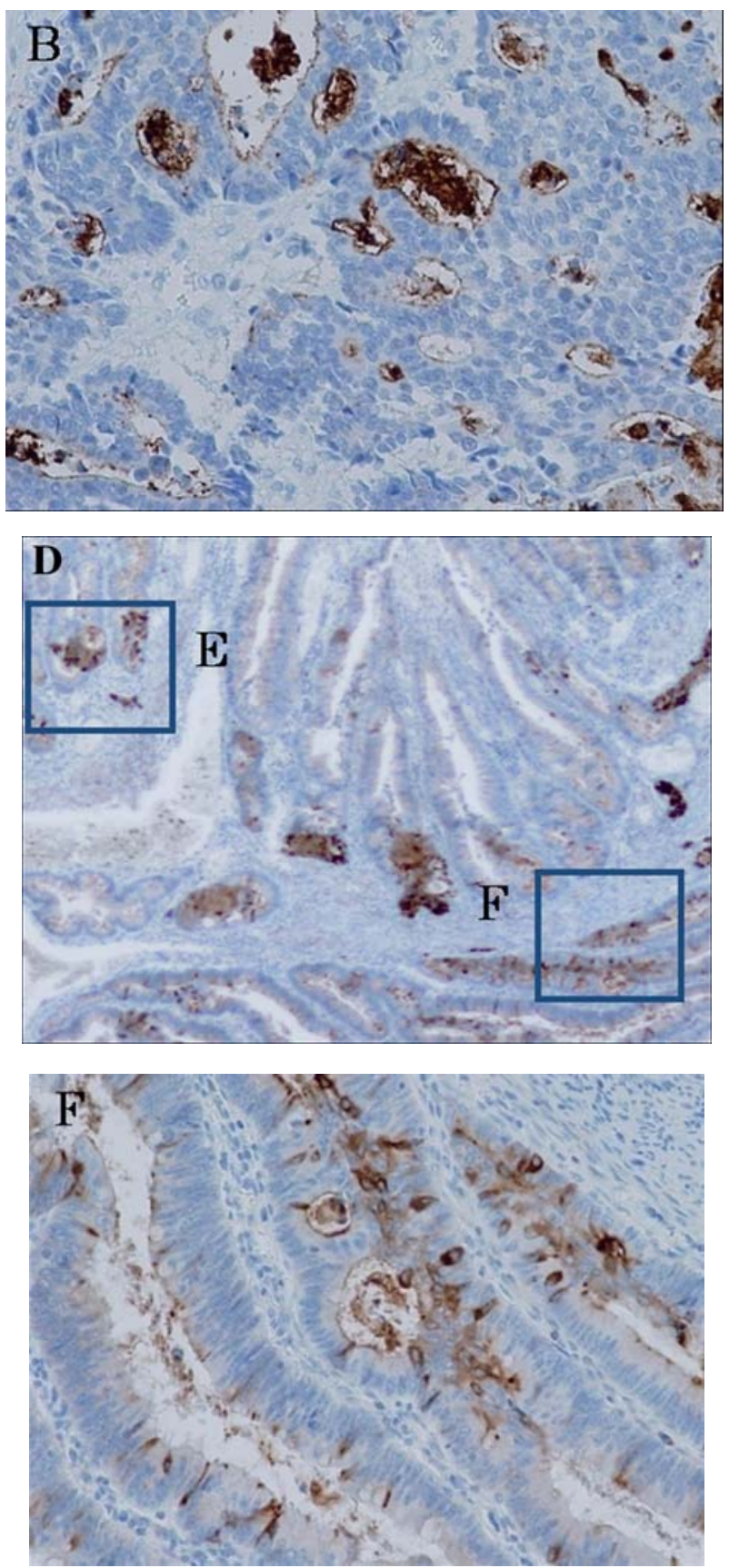

Figure 3. Distribution of CD133 expression: membranous and cytoplasmic, Membranous and cytoplasmic expression in separate areas (A), areas of membranous expression (B), area of cytoplasmic expression (C). Membranous and cytoplasmic expression in the same areas (D, E and F).

Correlation of CD133 overexpression with PS and RFS. The 5-year PS rates of 151 patients negative and positive for CD133 overexpression were 74.3 and $45.5 \%$, respectively. CD133 overexpression-positive patients showed significantly shorter overall survival than CD133 overexpression-negative patients $(\mathrm{p}=0.002)$ (Fig. 4A). The 5-year RFS rates of the 114 stage I-III patients (who underwent curative surgery) negative and positive for CD133 overexpression were 76.7 and $61.9 \%$, respectively; however, the difference was not significant ( $\mathrm{p}=0.08)$ (Fig. 4B).

Evaluation of membranous and cytoplasmic expression. With regard to membranous CD133 expression, the patients were divided into 2 categories: i) those with none or $<50 \%$ of stained cells on the membrane were defined as 'membranous overexpression negative'; and ii) those with $>50 \%$ of stained cells on the membrane were defined as 'membraneous overexpression positive'. Of the 151 patients, $126(83.4 \%)$ were membranous overexpression negative and $25(16.6 \%)$ were membranous overexpression positive.

Further, with regard to cytoplasmic CD133 expression, the patients were divided into 2 categories: i) those with no stained cells in the cytoplasm were defined as 'cytoplasmic expression negative'; and ii) those with stained cells in the cytoplasm were defined as 'cytoplasmic expression positive'. Of the 151 patients, 107 (70.9\%) were cytoplasmic expression negative and $44(29.1 \%)$ were cytoplasmic expression positive. 

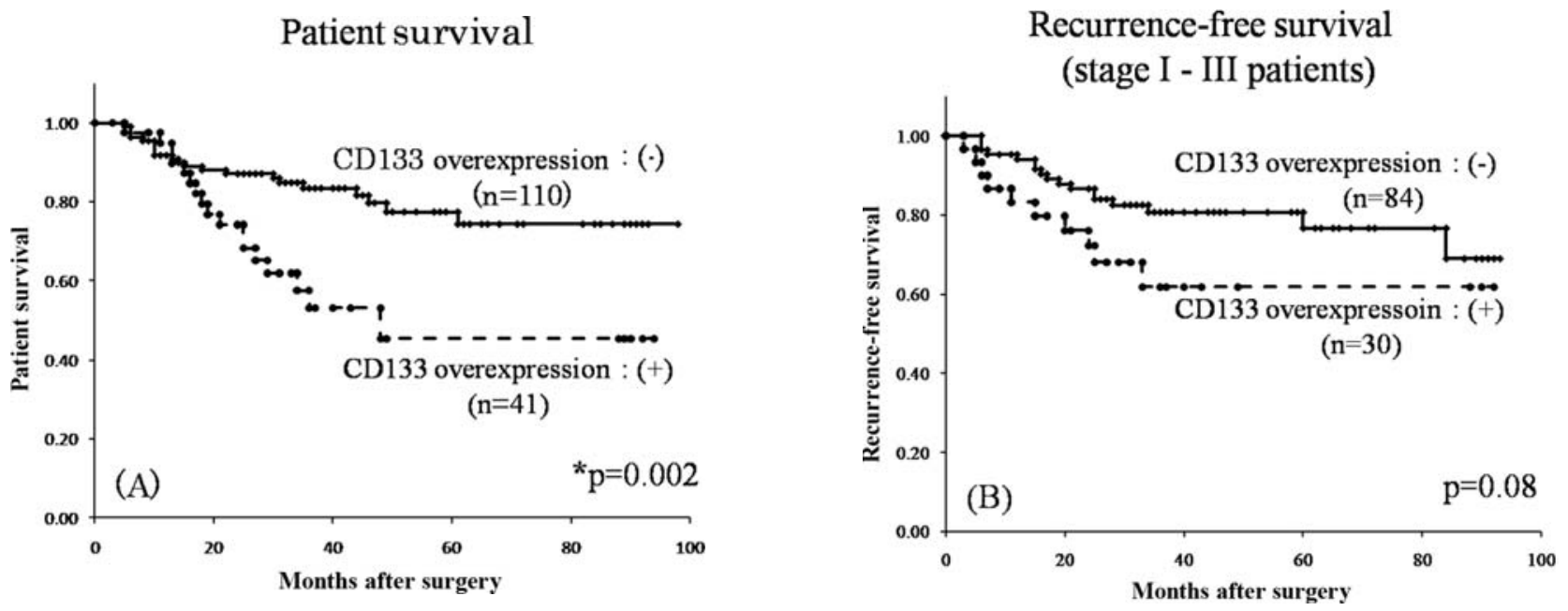

Figure 4. (A) Patient survival curves of 151 patients positive and negative for CD133 overexpression. CD133 overexpression-positive patients showed significantly shorter overall survival than CD133 overexpression-negative patients (log-rank test, $\mathrm{p}=0.002$ ). (B) Recurrence-free survival curves of 114 stage I-III patients (who underwent curative surgery) positive and negative for CD133 overexpression. Log-rank test did not indicate the difference in recurrencefree survival to be statistically significant $(\mathrm{p}=0.08)$.
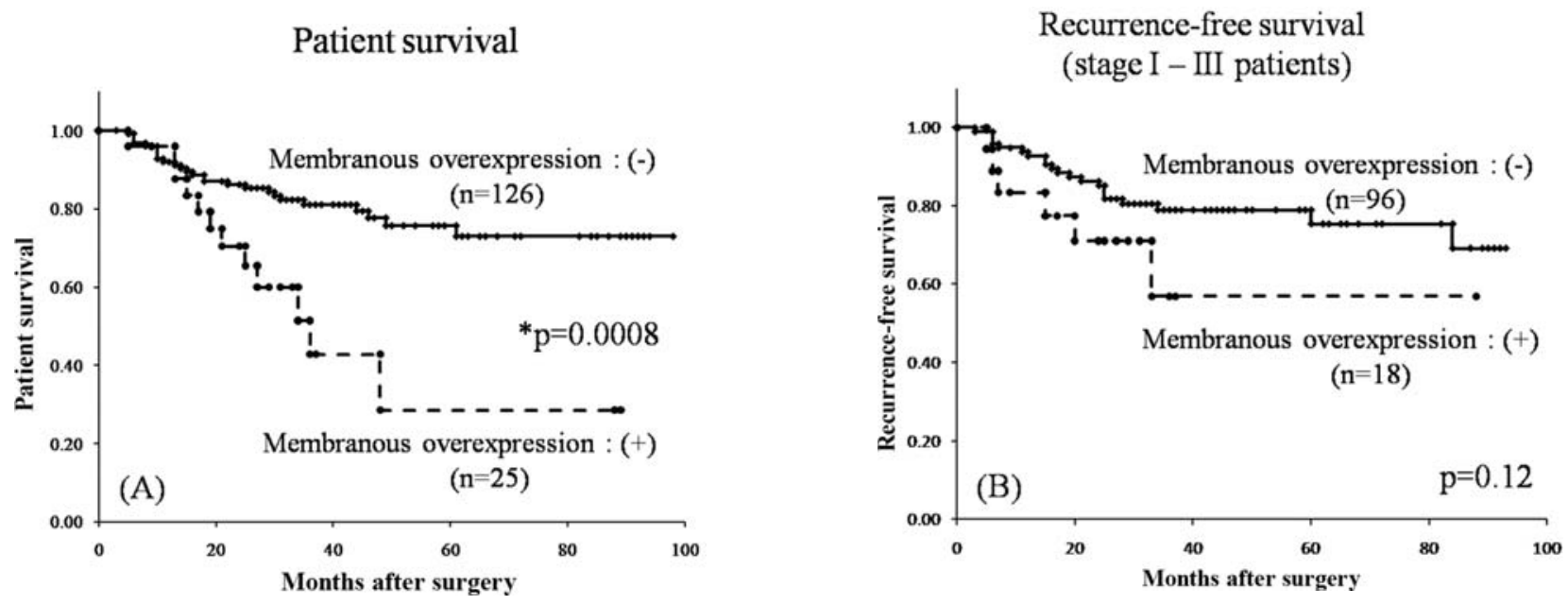

Figure 5. (A) Patient survival curves of 151 patients positive and negative for membranous CD133 overexpression. Membranous overexpression-positive patients showed significantly shorter overall survival than membranous overexpression-negative patients (log-rank test, $\mathrm{p}=0.0008)$. (B) Recurrencefree survival curves of 114 stage I-III patients (who underwent curative surgery) positive and negative for membranous CD133 overexpression. Logrank test did not indicate any statistically significant difference in recurrence-free survival $(\mathrm{p}=0.12)$

Correlation between CD133 expression pattern and clinicopathological features. As shown in Table IV, membranous overexpression significantly correlated with histology (welldifferentiated adenocarcinoma, $\mathrm{p}=0.019)$. Further, cytoplasmic expression significantly correlated with histology (moderately differentiated adenocarcinoma, $\mathrm{p}=0.0002$ ), lymph node metastasis ( $\mathrm{p}=0.0009)$, TNM stage (III + IV, $\mathrm{p}=0.03)$, and lymphatic invasion $(\mathrm{p}=0.0009)$.

Correlation of membranous overexpression with PS and RFS. Membranous overexpression-positive patients showed significantly shorter overall survival than membranous overexpression-negative patients $(\mathrm{p}=0.0008)$. Similar results were obtained for RFS, but the difference was not statistically significant ( $\mathrm{p}=0.12)$ (Fig. 5).
Correlation of cytoplasmic expression with PS and RFS. There was a significant difference in the overall survival shown by cytoplasmic expression-positive and cytoplasmic expressionnegative patients $(\mathrm{p}=0.01)$. Further, cytoplasmic expressionpositive patients showed significantly worse RFS than cytoplasmic expression-negative patients ( $\mathrm{p}=0.004)$ (Fig. 6).

Univariate and multivariate analyses of PS. Univariate analysis showed that PS was significantly correlated with tumor depth $(\mathrm{T})$, lymph node metastasis $(\mathrm{N})$, distant metastasis (M), liver metastasis, TNM stage, lymphatic invasion, vascular invasion, membranous overexpression, cytoplasmic expression, and CD133 overexpression. Multivariate analysis with tumor-associated factors showed distant metastasis (M, $\mathrm{p}<0.05)$, membranous overexpression $(\mathrm{p}=0.003)$, and CD133 
Table IV. Correlation between CD133 expression pattern and clinicopathological features.

\begin{tabular}{|c|c|c|c|c|c|c|}
\hline & \multicolumn{3}{|c|}{ Membranous overexpression } & \multicolumn{3}{|c|}{ Cytoplasmic expression } \\
\hline & Negative & Positive & & Negative & Positive & \\
\hline No. of patients & 126 & 25 & P-value & 107 & 44 & P-value \\
\hline \multicolumn{7}{|l|}{ Age } \\
\hline Year $($ mean $\pm \mathrm{SD})$ & $66.7 \pm 10.4$ & $69.1 \pm 0.3$ & 0.3 & $67.8 \pm 9.9$ & $65.5 \pm 1.3$ & 0.21 \\
\hline \multicolumn{7}{|l|}{ Sex } \\
\hline Male & 74 & 15 & 0.91 & 62 & 27 & 0.69 \\
\hline Female & 52 & 10 & & 45 & 17 & \\
\hline $\begin{array}{l}\text { Tumor size } \\
\text { mm }(\text { mean } \pm \mathrm{SD})\end{array}$ & $47.8 \pm 22.1$ & $52.0 \pm 36.2$ & 0.44 & $47.7 \pm 27.0$ & $50.3 \pm 18.9$ & 0.58 \\
\hline \multicolumn{7}{|l|}{ Tumor location } \\
\hline Right colon & 38 & 14 & Colon vs. rectum & 37 & 15 & Colon vs. rectum \\
\hline Left colon & 43 & 4 & & 34 & 13 & \\
\hline Rectum & 45 & 7 & 0.45 & 36 & 16 & 0.75 \\
\hline \multicolumn{7}{|l|}{ Histology } \\
\hline Well & 44 & $15^{\mathrm{a}}$ & $0.019^{\mathrm{a}}$ & 52 & 7 & $0.0002^{\mathrm{a}}$ \\
\hline Mod & 82 & 10 & & 55 & 37 & \\
\hline \multicolumn{7}{|l|}{ TNM parameter $(\mathrm{T})$} \\
\hline $\mathrm{T} 1$ & 14 & 3 & $\mathrm{~T} 1+\mathrm{T} 2$ vs. $\mathrm{T} 3+\mathrm{T} 4$ & 16 & 1 & $\mathrm{~T} 1+\mathrm{T} 2$ vs. $\mathrm{T} 3+\mathrm{T} 4$ \\
\hline $\mathrm{T} 2$ & 16 & 5 & 0.39 & 13 & 8 & 0.39 \\
\hline $\mathrm{T} 3$ & 67 & 9 & & 55 & 21 & \\
\hline $\mathrm{T} 4$ & 29 & 8 & & 23 & 14 & \\
\hline \multicolumn{7}{|l|}{ TNM parameter $(\mathrm{N})$} \\
\hline No & 64 & 15 & N (-) vs. N (+) & 66 & 13 & N (-) vs. N (+) \\
\hline N1 & 40 & 4 & 0.4 & 27 & $17^{\mathrm{a}}$ & $0.0009^{\mathrm{a}}$ \\
\hline N2 & 22 & 6 & & 14 & $14^{\mathrm{a}}$ & \\
\hline \multicolumn{7}{|l|}{ Liver metastasis } \\
\hline Absent & 104 & 21 & 0.86 & 92 & 33 & 0.1 \\
\hline Present & 22 & 4 & & 15 & 11 & \\
\hline \multicolumn{7}{|l|}{ TNM parameter (M) } \\
\hline M0 & 90 & 18 & 0.66 & 83 & 31 & 0.36 \\
\hline M1 & 36 & 7 & & 24 & 13 & \\
\hline \multicolumn{7}{|l|}{ TNM stage } \\
\hline I & 21 & 7 & I + II vs. III + IV & 23 & 5 & I + II vs. III + IV \\
\hline II & 38 & 7 & 0.44 & 37 & 8 & $0.03^{\mathrm{a}}$ \\
\hline III & 37 & 4 & & 23 & $18^{\mathrm{a}}$ & \\
\hline IV & 30 & 7 & & 24 & $13^{\mathrm{a}}$ & \\
\hline \multicolumn{7}{|l|}{ Lymphatic invasion } \\
\hline Absent & 29 & 9 & 0.17 & 35 & 2 & $0.0009^{\mathrm{a}}$ \\
\hline Present & 97 & 16 & & 72 & 41 & \\
\hline \multicolumn{7}{|l|}{ Vascular invasion } \\
\hline Absent & 58 & 12 & 0.86 & 55 & 15 & 0.05 \\
\hline Present & 68 & 13 & & 52 & 29 & \\
\hline
\end{tabular}

SD, standard deviation; well, well-differentiated adenocarcinoma; mod, moderately differentiated adenocarcinoma; TNM, tumor-node-metastasis; ${ }^{a}$ statistically significant.

overexpression $(\mathrm{p}=0.005)$ to be independent prognostic factors for PS (Table V).
Univariate and multivariate analyses of RFS. Univariate analysis showed that RFS was significantly correlated with 

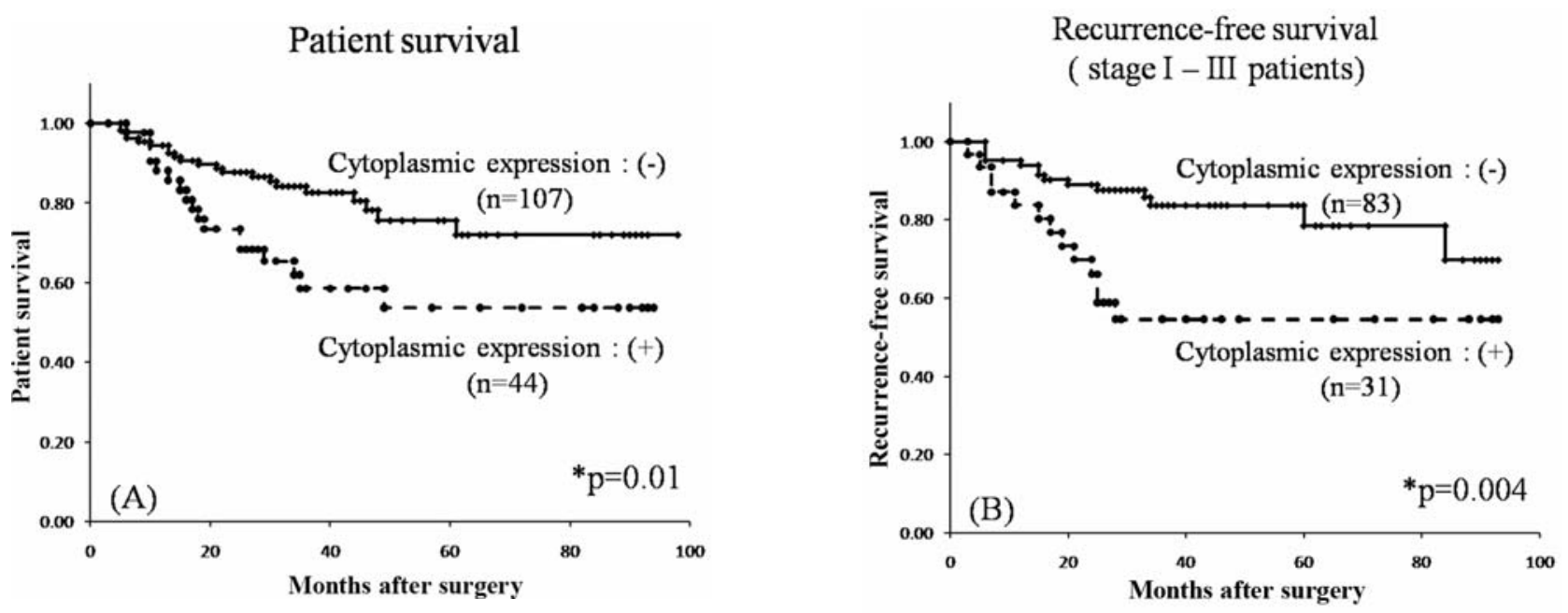

Figure 6. (A) Patient survival curves of 151 patients positive and negative for cytoplasmic CD133 expression. There was a significant difference in the overall survival of cytoplasmic expression-positive and cytoplasmic expression-negative patients (log-rank test, $\mathrm{p}=0.01$ ). (B) Recurrence-free survival curves of 114 stage I-III patients (who underwent curative surgery) positive and negative for cytoplasmic CD133 expression. Cytoplasmic expression-positive patients showed significantly worse recurrence-free survival than cytoplasmic expression-negative patients (log-rank test, $\mathrm{p}=0.004)$.

histology (moderately differentiated adenocarcinoma), lymph node metastasis $(\mathrm{N})$, lymphatic invasion, vascular invasion, and cytoplasmic expression. However, its correlation with CD133 overexpression was not statistically significant. Multivariate analysis with tumor-associated factors showed membranous overexpression to be an independent prognostic factor for RFS (Table VI).

Correlation between chemosensitivity and CD133 expression. To examine the correlation between the effect of chemotherapy and CD133 expression, 33 patients who received chemotherapy for tumor recurrence or stage IV tumors and showed measurable lesion(s) on computed tomography scans were examined. Tumor response was assessed according to the Response Evaluation Criteria in Solid Tumors (RECIST). Disease control rate was defined as the rate of the sum of complete response (CR), partial response (PR), and stable disease (SD). There was no significant difference in the disease control rates of CD133 overexpression-positive $(22.2 \%, 2 / 9)$ and CD133 overexpression-negative $(58.3 \% ; 14 / 24)$ patients $(\mathrm{p}=0.07)$ and those of cytoplasmic expression-positive patients $(35.7 \%, 5 / 14)$ and cytoplasmic expression-negative $(57.9 \%, 11 / 19)$ patients $(\mathrm{p}=0.21)$. The disease control rate of membranous overexpression-positive patients was $14.3 \%$ $(1 / 7)$, whereas that of membranous overexpression-negative patients was $57.7 \%(15 / 26)$. Membranous overexpressionpositive patients showed significant chemoresistance $(\mathrm{p}=0.04)$ (Table VII).

\section{Discussion}

CD133 overexpression was an independent prognostic factor for PS. Membranous overexpression, in particular, strongly correlated with PS, recurrence and chemoresistance. Cytoplasmic expression correlated with tumor progression, i.e., lymph node metastasis. Although the biological function of CD133 remains unclear, our results demonstrated that evaluation of the frequency and pattern of CD133 expression is useful for predicting prognosis, recurrence, and chemosensitivity in CRC patients.

CD133, also known as prominin-1, is a membrane protein containing 5 membrane-spanning domains, 2 large N-glycosylated extracellular loops, an extracellular $N$-terminal domain, and a cytoplasmic C-terminal domain (24). CD133 is mainly localized in membrane protrusions and microvilli (24). It is possible that CD133-positive cells in CRC are cancer stem cells. However, it is estimated that only 1 in 262 CD133positive CRC cells has tumor-initiation capability (9). Therefore, in this study, we immunohistochemically analyzed the frequency and pattern of CD133 expression in primary CRC patients. To our knowledge, this study is the first that evaluated the correlation between not only the frequency of CD133 expression but also its pattern (membranous or cytoplasmic) and clinicopathological features and the clinical significance of the frequency and pattern of CD133 expression in a large series of human CRC patients. With regard to the frequency of CD133 expression, it has been reported that CD133 expression rate is nearly $20 \%$ (22), and $>50 \%$ of glands stained positive for CD133 are seen in $>30 \%$ patients (23). In our study, CD133 expression rate was higher than that reported previously, and membranous expression $(90.1 \%$, $136 / 151)$ was more frequent than cytoplasmic expression $(29.1 \%, 44 / 151)$. Both expression patterns were shown by $27.8 \%(42 / 151)$ patients.

Some previous studies on the clinical significance of the frequency of CD133 expression in CRC have been reported $(22,23,25-28)$. In this study, CD133 overexpression was significantly correlated with PS and was an independent prognostic factor. This finding is in agreement with those indicated in previous reports of Horst et al and other researchers $(23,25,26)$. Horst et al speculated that CD133-expressing tumor cell population may have additional cellular characteristics that contribute to the aggressiveness (tumor progression) of CRC, such as increased cell motility, invasion, or 
Table V. Univariate and multivariate analyses of patient survival.

\begin{tabular}{|c|c|c|c|c|c|c|c|c|c|}
\hline \multirow[b]{2}{*}{ No. of patients } & \multicolumn{3}{|c|}{ Univariate analysis } & \multicolumn{3}{|c|}{ Multivariate analysis 1} & \multicolumn{3}{|c|}{ Multivariate analysis 2} \\
\hline & $\mathrm{n}=151$ & 5-year survival (\%) & P-value & HR & $95 \% \mathrm{CI}$ & P-value & HR & $95 \% \mathrm{CI}$ & P-value \\
\hline \multicolumn{10}{|l|}{ Age (years) } \\
\hline$\leq 67$ & 67 & 71.5 & 0.68 & ND & & & ND & & \\
\hline$>67$ & 84 & 76.5 & & & & & & & \\
\hline \multicolumn{10}{|l|}{ Sex } \\
\hline Male & 89 & 67.1 & 0.22 & ND & & & ND & & \\
\hline Female & 62 & 71.3 & & & & & & & \\
\hline \multicolumn{10}{|l|}{ Histology } \\
\hline Well & 59 & 66.7 & 0.74 & 1 & & & 0.8 & $0.34-1.88$ & 0.61 \\
\hline Mod & 92 & 75.8 & & 1.004 & $0.47-2.12$ & 0.99 & 1 & & \\
\hline \multicolumn{10}{|l|}{ Tumor location } \\
\hline Colon & 99 & 65.1 & 0.21 & 1 & & & 1 & & \\
\hline Rectum & 52 & 75.5 & & 0.55 & $0.25-1.21$ & 0.14 & 0.56 & $0.25-1.24$ & 0.15 \\
\hline \multicolumn{10}{|c|}{ Tumor size $(\mathrm{mm})$} \\
\hline$\leq 48$ & 73 & 74.8 & 0.26 & 0.92 & $0.44-1.92$ & 0.84 & 0.88 & $0.42-1.82$ & 0.73 \\
\hline$>48$ & 78 & 64.8 & & 1 & & & 1 & & \\
\hline \multicolumn{10}{|c|}{ TNM parameter $(\mathrm{T})$} \\
\hline $\mathrm{T} 1+\mathrm{T} 2$ & 38 & 92.1 & $0.006^{\mathrm{a}}$ & 1 & & & 0.97 & $0.23-4.01$ & 0.97 \\
\hline $\mathrm{T} 3+\mathrm{T} 4$ & 113 & 61.8 & & 1.02 & $0.26-3.99$ & 0.97 & 1 & & \\
\hline \multicolumn{10}{|c|}{ TNM parameter $(\mathrm{N})$} \\
\hline $\mathrm{N}(-)$ & 79 & 88.0 & $<0.0001^{\mathrm{a}}$ & 1 & & & 1 & & \\
\hline $\mathrm{N}(+)$ & 72 & 49.4 & & 3.03 & $0.64-14.3$ & 0.16 & 2.61 & $0.53-12.7$ & 0.23 \\
\hline \multicolumn{10}{|c|}{ TNM parameter $(\mathrm{M})$} \\
\hline M0 & 114 & 80.9 & $<0.0001^{\mathrm{a}}$ & 1 & & & 1 & & \\
\hline M1 & 37 & 33.1 & & 3.16 & $1.13-8.86$ & $0.02^{\mathrm{a}}$ & 3.05 & $1.10-8.44$ & $0.03^{\mathrm{a}}$ \\
\hline \multicolumn{10}{|l|}{ Liver metastasis } \\
\hline Absent & 125 & 77.3 & $<0.0001^{\mathrm{a}}$ & 1 & & & 1 & & \\
\hline Present & 26 & 29.6 & & 2.34 & $0.91-5.99$ & 0.07 & 2.39 & $0.95-5.97$ & 0.06 \\
\hline \multicolumn{10}{|l|}{ TNM stage } \\
\hline $\mathrm{I}+\mathrm{II}$ & 73 & 88.1 & $<0.0001^{\mathrm{a}}$ & 1 & & & 1 & & \\
\hline III + IV & 78 & 52.5 & & 2.08 & $0.07-3.66$ & 0.51 & 1.72 & $0.08-4.16$ & 0.59 \\
\hline \multicolumn{10}{|c|}{ Lymphatic invasion } \\
\hline Absent & 38 & 97.3 & $0.0004^{\mathrm{a}}$ & 1 & & & 1 & & \\
\hline Present & 113 & 60.0 & & 5.99 & $0.71-50.4$ & 0.09 & 6.7 & $0.76-58.5$ & 0.08 \\
\hline \multicolumn{10}{|c|}{ Vascular invasion } \\
\hline Absent & 70 & 89.4 & $<0.0001^{\mathrm{a}}$ & 1 & & & 1 & & \\
\hline Present & 81 & 50.7 & & 2.28 & $0.71-7.27$ & 0.16 & 2.27 & $0.69-7.38$ & 0.17 \\
\hline \multicolumn{10}{|c|}{ Membranous overexpression } \\
\hline Negative & 126 & 75.8 & $0.0008^{\mathrm{a}}$ & ND & & & 1 & & \\
\hline Positive & 25 & 28.6 & & & & & 3.29 & $1.49-7.24$ & $0.003^{\mathrm{a}}$ \\
\hline \multicolumn{10}{|c|}{ Cytoplasmic expression } \\
\hline Negative & 107 & 75.6 & $0.01^{\mathrm{a}}$ & ND & & & 1 & & \\
\hline Positive & 44 & 53.7 & & & & & 1.86 & $0.86-4.02$ & 0.11 \\
\hline \multicolumn{10}{|c|}{ CD133 overexpression } \\
\hline Negative & 110 & 77.4 & $0.002^{\mathrm{a}}$ & 1 & & & ND & & \\
\hline Positive & 41 & 45.5 & & 2.87 & $1.37-5.99$ & $0.005^{\mathrm{a}}$ & & & \\
\hline
\end{tabular}

HR, hazard ratio; 95\% CI, 95\% confidence interval; ND, not determined; well, well-differentiated adenocarcinoma; mod, moderately differentiated

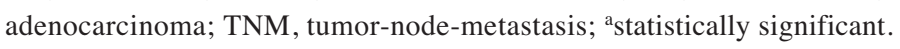


Table VI. Univariate and multivariate analyses of recurrence free survival.

\begin{tabular}{|c|c|c|c|c|c|c|c|c|c|}
\hline \multirow[b]{2}{*}{ No. of patients } & \multicolumn{3}{|c|}{ Univariate analysis } & \multicolumn{3}{|c|}{ Multivariate analysis 1} & \multicolumn{3}{|c|}{ Multivariate analysis 2} \\
\hline & $\mathrm{n}=114$ & $\begin{array}{c}\text { 5-year } \\
\text { recurrence-free } \\
\text { survival }(\%)\end{array}$ & P-value & HR & $95 \% \mathrm{CI}$ & P-value & HR & $95 \% \mathrm{CI}$ & P-value \\
\hline \multicolumn{10}{|l|}{ Age (years) } \\
\hline$\leq 67$ & 46 & 77.7 & 0.76 & ND & & & ND & & \\
\hline$>67$ & 68 & 74.8 & & & & & & & \\
\hline \multicolumn{10}{|l|}{ Sex } \\
\hline Male & 62 & 72.8 & 0.41 & ND & & & ND & & \\
\hline Female & 52 & 80.0 & & & & & & & \\
\hline \multicolumn{10}{|l|}{ Histology } \\
\hline Well & 47 & 84.6 & $0.045^{\mathrm{a}}$ & 1 & & & 1 & & \\
\hline Mod & 67 & 70.3 & & 1.62 & $0.62-4.22$ & 0.31 & 1.7 & $0.60-4.80$ & 0.31 \\
\hline \multicolumn{10}{|l|}{ Tumor location } \\
\hline Colon & 74 & 74.7 & 0.18 & 1 & & & 1 & & \\
\hline Rectum & 40 & 66.5 & & 1.51 & $0.65-3.49$ & 0.33 & 1.52 & $0.64-3.58$ & 0.33 \\
\hline \multicolumn{10}{|c|}{ Tumor size (mm) } \\
\hline$\leq 48$ & 60 & 76.9 & 0.93 & 1 & & & 1 & & \\
\hline$>48$ & 54 & 75.4 & & 0.67 & $0.28-1.61$ & 0.37 & 0.67 & $0.28-1.57$ & 0.36 \\
\hline \multicolumn{10}{|c|}{ TNM parameter $(\mathrm{T})$} \\
\hline $\mathrm{T} 1+\mathrm{T} 2$ & 36 & 82.3 & 0.19 & 1 & & & 1 & & \\
\hline $\mathrm{T} 3+\mathrm{T} 4$ & 78 & 72.9 & & 1.15 & $0.37-3.55$ & 0.8 & 1.44 & $0.44-4.67$ & 0.53 \\
\hline \multicolumn{10}{|c|}{ TNM parameter $(\mathrm{N})$} \\
\hline $\mathrm{N}(-)$ & 73 & 83.5 & $0.01^{\mathrm{a}}$ & 1 & & & 1 & & \\
\hline $\mathrm{N}(+)$ & 41 & 62.9 & & 1.47 & $0.62-3.44$ & 0.37 & 1.41 & $0.58-3.43$ & 0.44 \\
\hline \multicolumn{10}{|c|}{ Lymphatic invasion } \\
\hline Absent & 36 & 94.1 & $0.008^{\mathrm{a}}$ & 1 & & & 1 & & \\
\hline Present & 78 & 67.5 & & 2.7 & $0.69-10.6$ & 0.15 & 2.47 & $0.60-10.1$ & 0.2 \\
\hline \multicolumn{10}{|c|}{ Vascular invasion } \\
\hline Absent & 68 & 83.9 & $0.009^{\mathrm{a}}$ & 1 & & & 1 & & \\
\hline Present & 46 & 64.0 & & 1.49 & $0.59-3.74$ & 0.38 & 1.41 & $0.55-3.58$ & 0.46 \\
\hline \multicolumn{10}{|c|}{ Membranous overexpression } \\
\hline Negative & 96 & 78.8 & 0.12 & ND & & & 1 & & \\
\hline Positive & 18 & 56.7 & & & & & 3.92 & $1.42-10.7$ & $0.008^{\mathrm{a}}$ \\
\hline \multicolumn{10}{|c|}{ Cytoplasmic expression } \\
\hline Negative & 83 & 83.7 & $0.004^{\mathrm{a}}$ & ND & & & 1 & & \\
\hline Positive & 31 & 54.6 & & & & & 2 & $0.86-4.65$ & 0.1 \\
\hline \multicolumn{10}{|c|}{ CD133 overexpression } \\
\hline Negative & 84 & 80.7 & 0.08 & 1 & & & ND & & \\
\hline Positive & 30 & 61.9 & & 2.13 & $0.95-4.73$ & 0.06 & & & \\
\hline
\end{tabular}

HR, hazard ratio; 95\% CI, 95\% confidence interval; ND, not determined; well, well-differentiated adenocarcinoma; mod, moderately differentiated

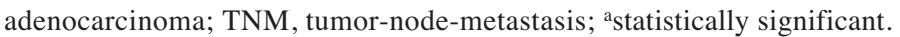

migration capabilities; colonization of distant organs; and growth of metastatic tumors, besides pure tumor initiation $(29,30)$.
Further, in our study, the pattern of CD133 expression in tumor cells was divided into 'membranous expression', which was observed on the cell membrane as apical mem- 
Table VII. Correlation between chemosensitivity and CD133 expression.

\begin{tabular}{|c|c|c|c|c|}
\hline & $\mathrm{n}$ & $\mathrm{PD}(\%)$ & $\mathrm{CR}+\mathrm{PR}+\mathrm{SD}(\%)$ & P-value \\
\hline \multicolumn{5}{|c|}{ CD133 overexpression } \\
\hline Negative & 24 & $10(41.7)$ & $14(58.3)$ & \\
\hline Positive & 9 & $7(77.8)$ & $2(22.2)$ & 0.07 \\
\hline \multicolumn{5}{|c|}{ Membranous overexpression } \\
\hline Negative & 26 & $11(42.3)$ & $15(57.7)$ & \\
\hline Positive & 7 & $6(85.7)$ & $1(14.3)^{\mathrm{a}}$ & $0.04^{\mathrm{a}}$ \\
\hline \multicolumn{5}{|c|}{ Cytoplasmic expression } \\
\hline Negative & 19 & $8(42.1)$ & $11(57.9)$ & \\
\hline Positive & 14 & $9(64.4)$ & $5(35.7)$ & 0.21 \\
\hline
\end{tabular}

PD, progressive disease; CR, complete response; PR, partial response; SD, stable disease; ${ }^{a}$ statistically significant.

branous staining, and 'cytoplasmic expression', which was observed in the cytoplasm as a strong dotty or uniform pattern, by using the rabbit anti-human polyclonal CD133 primary antibody (ab19898; Abcam). Many reports on the pattern and immunolocalization of CD133 expression in CRC describe that CD133 expression is mainly detected on the cell membrane at the luminal surface of the cancer gland $(22,23,25,26)$. However, in some studies including ours, it was reported that cytoplasmic CD133 expression is detected in CRC $(27,28)$. Moreover, cytoplasmic CD133 expression has been reported in other solid malignant tumors [pancreatic cancer (31), hepatocellular carcinoma (32), glioma (33), and ovarian carcinoma (34)]. Recent studies on pancreatic cancer have shown that apical/endoluminal membranous staining for CD133 expression is characteristic of welloriented, polarized, and differentiated cells, whereas cytoplasmic staining for CD133 expression is found in a small population of cells; this suggests that cytoplasmic staining for CD133 in cancer cells is indicative of putative cancer stem cells (35). Analysis of immunolocalization (membranous and cytoplasmic expression) of CD24 $(36,37)$ and human epidermal growth factor receptor 2 (HER-2) $(38,39)$ has been reported in various tumors. CD24 is defined as a cancer stem cell surface marker (40). In the studies cited above, it was speculated that immunolocalization of CD24 may reflect overproduction, disturbance of distribution or degradation within cells. HER-2 is a member of the family of type- 1 growth factor receptors, and this family of receptors is crucial for mediating proliferation, differentiation, and survival of normal cells (39). Cytoplasmic expression of HER-2 may either be artifactual or may represent a cross-reacting protein or a precursor form of the mature protein (39). Although it is unclear whether immunolocalization (membranous or cytoplasmic expression) of CD133 reflects different cellular functions, this study showed different clinical significance of CD133 expression depending on CD133 immunolocalization. Membranous overexpression correlated with PS, RFS and chemoresistance. Cytoplasmic expression correlated with tumor progression, i.e., lymph node metastasis, but it was not an independent marker for PS and disease recurrence. It is supposed that these clinical findings are related to the characteristics of CD133-positive cancer stem cells although stem cell-like properties have recently been reported in CD133-negative cells in CRC (41). Chemoresistance due to membranous overexpression may be associated with poor PS after recurrence and consequent poor PS of CD133 expression-positive patients. With regard to the correlation between immunolocalization and clinical significance of CD24 expression, Weichert et al (36) speculated that shift from apical membranous localization to cytoplasmic localization reflects the transition of epithelial cells to a more invasive phenotype. However because membranous overexpression correlated with PS and RFS in this study but cytoplasmic expression did not, a mechanism opposite to that of CD24 may be considered to be involved in the correlation between immunolocalization and malignant phenotype of CD133 in CRC.

In conclusion, immunohistochemistry showed that CD133 expression has clinical significance and evaluation of the frequency and pattern of CD133 expression is useful for predicting recurrence, chemosensitivity, and poor prognosis in CRC patients.

\section{References}

1. Jemal A, Siegel R, Ward E, Murray T, Xu J, Smigal C and Thun MJ: Cancer statistics, 2006. CA Cancer J Clin 56: 106-130, 2006.

2. Japanese Society for Cancer of the Colon and Rectum: JSCCR Guidelines 2010 for the Treatment of Colorectal Cancer (in Japanese). Kanehara Shuppan, Tokyo, pp59-61, 2010.

3. Meyerhardt JA and Mayer RJ: Systemic therapy for colorectal cancer. N Engl J Med 352: 476-487, 2005.

4. Jemal A, Siegel R, Ward E, Murray T, Xu J, Smigal C and Thun MJ: Cancer statistics, 2008. CA Cancer J Clin 58: 71-96, 2008.

5. Omura K: Advances in chemotherapy against advanced or metastatic colorectal cancer. Digestion 77 (Suppl. 1): 13-22, 2008.

6. Hecht JR: Current and emerging therapies for metastatic colorectal cancer: applying research findings to clinical practice. Am J Health Syst Pharm 65 (11 Suppl. 4): S15S21, 2008.

7. Reya T, Morrison SJ, Clarke MF and Weissman IL: Stem cells, cancer, and cancer stem cells. Nature 414: 105-111, 2001. 
8. Bonnet D and Dick JE: Human acute myeloid leukemia is organized as a hierarchy that originates from a primitive hematopoietic cell. Nat Med 3: 730-737, 1997.

9. O'Brien CA, Pollett A, Gallinger S and Dick JE: A human colon cancer cell capable of initiating tumour growth in immunodeficient mice. Nature 445: 106-110, 2007.

10. Ricci-Vitiani L, Lombardi DG, Pilozzi E, Biffoni M, Todaro M, Peschle $\mathrm{C}$ and De Maria R: Identification and expansion of human colon cancer-initiating cells. Nature 445: 111-115, 2007.

11. Yuan X, Curtin J, Xiong Y, Liu G, Waschsmann-Hogiu S, Farkas DL, Black KL and Yu JS: Isolation of cancer stem cells from adult glioblastoma multiforme. Oncogene 23: 9392-9400, 2004.

12. Ponti D, Costa A, Zaffaroni N, Pratesi G, Petrangolini G, Coradini D, Pilotti S, Pierotti MA and Daidone MG: Isolation and in vitro propagation of tumorigenic breast cancer cells with stem/progenitor cell properties. Cancer Res 65: 5506-5511, 2005.

13. Haraguchi N, Utsunomiya $\mathrm{T}$, Inoue $\mathrm{H}$, Tanaka $\mathrm{F}$, Mimori $\mathrm{K}$, Barnard GF and Mori M: Characterization of a side population of cancer cells from human gastrointestinal system. Stem Cells 24: 506-513, 2006.

14. Patrawala L, Calhoun T, Schneider-Broussard R, Li H, Bhatia B, Tang S, Reilly JG, Chandra D, Zhou J, Claypool K, Coghlan L and Tang DG: Highly purified CD44+ ${ }^{+}$prostate cancer cells from xenograft human tumors are enriched in tumorigenic and metastatic progenitor cells. Oncogene 25: 1696-1708, 2006.

15. Al-Hajj M, Becker MW, Wicha M, Weissman I and Clarke MF: Therapeutic implications of cancer stem cells. Curr Opin Genet Dev 14: 43-47, 2004

16. Yin AH, Miraglia S, Zanjani ED, Almeida-Porada G, Ogawa M, Leary AG, Olweus J, Kearney J and Buck DW: AC133, a novel marker for human hematopoietic stem and progenitor cells. Blood 90: 5002-5012, 1997

17. Singh SK, Hawkins C, Clarke ID, Squire JA, Bayani J, Hide T, Henkelman RM, Cusimano MD and Dirks PB: Identification of human brain tumour initiating cells. Nature 432: 396-401, 2004

18. Collins AT, Berry PA, Hyde C, Stower MJ and Maitland NJ: Prospective identification of tumorigenic prostate cancer stem cells. Cancer Res 65: 10946-10951, 2005.

19. Hermann PC, Huber SL, Herrler T, Aicher A, Ellwart JW, Guba M, Bruns CJ and Heeschen C: Distinct populations of cancer stem cells determine tumor growth and metastatic activity in human pancreatic cancer. Cell Stem Cell 1: 313-323, 2007.

20. Bao S, Wu Q, McLendon RE, Hao Y, Shi Q, Hjelmeland AB, Dewhirst MW, Bigner DD and Rich JN: Glioma stem cells promote radioresistance by preferential activation of the DNA damage response. Nature 444: 756-760, 2006.

21. Mehra N, Penning M, Maas J, Beerepoot LV, van Daal N, van Gils CH, Giles RH and Voest EF: Progenitor marker CD133 mRNA is elevated in peripheral blood of cancer patients with bone metastases. Clin Cancer Res 12: 4859-4866, 2006.

22. Kojima M, Ishii G, Atsumi N, Fujii S, Saito N and Ochiai A: Immunohistochemical detection of CD133 expression in colorectal cancer: a clinicopathological study. Cancer Sci 99: 1578-1583, 2008.

23. Horst D, Kriegl L, Engel J, Kirchner T and Jung A: CD133 expression is an independent prognostic marker for low survival in colorectal cancer. Br J Cancer 99: 1285-1289, 2008.

24. Corbeil D, Röper K, Fargeas CA, Joester A and Huttner WB: Prominin: a story of cholesterol, plasma membrane protrusions and human pathology. Traffic 2: 82-91, 2001

25. Li CY, Li BX, Liang Y, Peng RQ, Ding Y, Xu DZ, Zhang X, Pan ZZ, Wan DS, Zeng YX, Zhu XF and Zhang XS: Higher percentage of $\mathrm{CD} 133^{+}$cells is associated with poor prognosis in colon carcinoma patients with stage IIIB. J Transl Med 7: 56,2009
26. Wang Q, Chen ZG, Du CZ, Wang HW, Yan L and Gu J: Cancer stem cell marker CD133+ tumour cells and clinical outcome in rectal cancer. Histopathology 55: 284-293, 2009.

27. Saigusa S, Tanaka K, Toiyama Y, Yokoe T, Okugawa Y, Ioue Y, Miki C and Kusunoki M: Correlation of CD133, OCT4, and SOX2 in rectal cancer and their association with distant recurrence after chemoradiotherapy. Ann Surg Oncol 16: 3488-3498, 2009.

28. Choi D, Lee HW, Hur KY, Kim JJ, Park GS, Jang SH, Song YS, Jang KS and Paik SS: Cancer stem cell markers CD133 and CD24 correlate with invasiveness and differentiation in colorectal adenocarcinoma. World J Gastroenterol 15: 2258-2264, 2009

29. Horst D, Scheel SK, Liebmann S, Neumann J, Maatz S, Kirchner T and Jung A: The cancer stem cell marker CD133 has high prognostic impact but unknown functional relevance for the metastasis of human colon cancer. J Pathol 219: 427-434, 2009.

30. Horst D, Kriegl L, Engel J, Kirchner T and Jung A: Prognostic significance of the cancer stem cell markers CD133, CD44, and CD166 in colorectal cancer. Cancer Invest 27: 844-850, 2009.

31. Maeda S, Shinchi H, Kurahara H, Mataki Y, Maemura K, Sato M, Natsugoe S, Aikou T and Takao S: CD133 expression is correlated with lymph node metastasis and vascular endothelial growth factor-C expression in pancreatic cancer. Br J Cancer 98: 1389-1397, 2008.

32. Song W, Li H, Tao K, Li R, Song Z, Zhao Q, Zhang F and Dou K: Expression and clinical significance of the stem cell marker CD133 in hepatocellular carcinoma. Int J Clin Pract 62: 1212-1218, 2008.

33. Zhang $\mathrm{M}$, Song $\mathrm{T}$, Yang $\mathrm{L}$, Chen $\mathrm{R}$, Wu L, Yang $\mathrm{Z}$ and Fang $\mathrm{J}$ : Nestin and CD133: valuable stem cell-specific markers for determining clinical outcome of glioma patients. J Exp Clin Cancer Res 27: 85, 2008.

34. Ferrandina G, Martinelli E, Petrillo M, Prisco MG, Zannoni G, Sioletic S and Scambia G: CD133 antigen expression in ovarian cancer. BMC Cancer 9: 221, 2009.

35. Immervoll H, Hoem D, Sakariassen PØ, Steffensen OJ and Molven A: Expression of the 'stem cell marker' CD133 in pancreas and pancreatic ductal adenocarcinomas. BMC Cancer 8: 48,2008 .

36. Weichert W, Denkert C, Burkhardt M, Gansukh T, Bellach J Altevogt P, Dietel M and Kristiansen G: Cytoplasmic CD24 expression in colorectal cancer independently correlates with shortened patient survival. Clin Cancer Res 11: 6574-6581, 2005.

37. Kristiansen G, Denkert C, Schlüns K, Dahl E, Pilarsky C and Hauptmann S: CD24 is expressed in ovarian cancer and is a new independent prognostic marker of patient survival. Am J Pathol 161: 1215-1221, 2002.

38. Cheng CM, Tsuneyama K, Matsui K, Takahashi H, Ishizawa S and Takano Y: Cytoplasmic expression of c-erbB2 in nonsmall cell lung cancers. Virchows Arch 446: 596-603, 2005.

39. Pavlakis K, Kountourakis P, Stathopoulos E, Psyrri A, Rontogianni D, Kafousi M, Derivianaki M, Xiros N, Pectasides D and Economopoulos T: Her-2 protein expression, cellular localization, and gene amplification in colorectal carcinoma. Appl Immunohistochem Mol Morphol 15: 441-445, 2007.

40. Kruger JA, Kaplan CD, Luo Y, Zhou H, Markowitz D, Xiang R and Reisfeld RA: Characterization of stem cell-like cancer cells in immune-component mice. Blood 108: 3906-3912, 2006.

41. Shmelkov SV, Butler JM, Hooper AT, Hormigo A, Kushner J, Milde T, St Clair R, Baljevic M, White I, Jin DK, Chadburn A, Murphy AJ, Valenzuela DM, Gale NW, Thurston G, Yancopoulos GD, D'Angelica M, Kemeny N, Lyden D and Rafii S: CD133 expression is not restricted to stem cells, and both $\mathrm{CD}_{133^{+}}$and CD133- metastatic colon cancer cells initiate tumors. J Clin Invest 118: 2111-2120, 2008. 